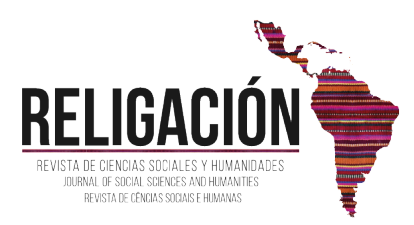

Sección Sur-Sur

\title{
Light and color in Islamic mysticism and architecture
}

\author{
Luzy color en el misticismo y la arquitectura islámica
}

Saba Mazaheri | Islamic Azad University - IRAN |

Master's Degree of Architecture, Department of Science and Research. E-mail: sabamazaheri89@gmail.com

Abdolreza Mazaheri | Islamic Azad University - IRAN |

Member of faculty and professor of Islamic Azad University, Central Tehran Branch. E-mail: mazaheri711@yahoo.com

\begin{abstract}
This paper aims to study the cognitive background of light and color in the culture and art of Islamic mysticism and architecture analytically. Islamic mysticism and architecture are two separate disciplines that pursue a common goal in light and color about the creation of the universe and its emergence in different realms. Architecture tries to express the delicate mystical aspects of this matter in the material world. The mysticism supposes the universe or the light of all lights begins from God, and this light, which is an aspect of existence, will be darker passing to the lower worlds. As the world of reason, the first universe, is white, and the world of the body, which is the last known universe, is black. The findings show that light and color are two fundamental elements of creation and existence, which, by mixing in Islamic mysticism and architecture, have found a new identity and have created a vast global vision toward Allah. This essay is based on an interpretive analytical method, based on Clifford Geertz's interpretations theories and functionalism of Branislaw Malinowski, based on a library and documentary methodology and a qualitative content analysis method that transforms from descriptive to interpretive.
\end{abstract}

Keywords: light, color, architecture, mysticism, world of reason, universe.

RESUMEN: El objetivo de este artículo es estudiar analíticamente los antecedentes cognitivos de la luz y el color en la cultura y el arte del misticismo y la arquitectura islámicos. El misticismo y la arquitectura islámicos son dos disciplinas separadas que persiguen un objetivo común en luz y color sobre la creación del universo y su aparición en diferentes ámbitos. La arquitectura trata de expresar los delicados aspectos místicos de esta materia en el mundo material. El misticismo supone que el universo o la luz de todas las luces comienza desde Dios, y esta luz, que es un aspecto de la existencia, será más oscura y pasará a los mundos inferiores. Como el mundo de la razón, el primer universo, es blanco, y el mundo del cuerpo, que es el último universo conocido, es negro. Los resultados muestran que la luz y el color son dos elementos fundamentales de la creación y la existencia que, al mezclarse con el misticismo y la arquitectura islámicos, han encontrado una nueva identidad y han creado una vasta visión global hacia Allah. Para este propósito se utilizó el método analítico interpretativo, basado en las teorías de interpretación de Clifford Geertz y funcionalismo de Branislaw Malinowski, con una metodología de biblioteca, documental y un método de análisis de contenido cualitativo que se transforma de descriptivo a interpretativo.

Palabras clave: luz, color, arquitectura, misticismo, mundo y razón, universo. 


\section{INTRODUCTION}

From a mystical point of view, a light that manifests itself from the high universe and begins to move in a downward as a curve, is always worthwhile to study from various religious, mystical, artistic and philosophical sights. In every world, according to the container of that same world, it takes a special color. The mysticism of Islam called them as the seven universes for which they are given a special color based on their closeness and dimension than the God, and on the other hand, in the arc of ascension, which man must pass his/ her existence journey through seven stages, the same light of guidance in any stage takes on a special color corresponding to that particular stage, which will be mentioned in the discussion of these seven internal stages .

The findings show that in architecture, any color with regard to these stages has been used in the arch of ascension or descension. Al-Farabi also placed architecture in the mechanic geometry and called it Alam al-Hail. He was the innovator of the architecture and made the art as a transcendental concept (Najiboglu, 2000: 188). In this regard, Sohrevardi was founded the light-based wisdom which influenced on art and architecture significantly, and his thoughts had a dramatic effect in the ideas of Njameddin Kobra, Najm Razi, Roozbehan Baqli and Alaa al-Dawlah Semnani, which led to a special attitude towards light and color. This attitude opened the way of mystical themes into Islamic architecture and art (Nasr, 1982, 82), and according to Burkhart, the architect made its material foundation (Burkhart, 1991, 23). So, one of the signs of religious and heavenly knowledge is to recognize the color, light and the meaningful illuminations of creation of both worlds by the Lord, which is examined in this paper by relying on Islamic mysticism.

This article attempts to find an appropriate answer how the light and color in the worlds, the mystical stages \& status mingled to the architecture, how are they govern the hidden or obvious origin. For example, shadow and light, which is one of the main pillars of architecture, and this discussion has borrowed the concept of creation of light in the darkness of Islamic mysticism, and because the material in this space conforms to the heavenly teachings and the universal definitions of the psychology of colors, the temporary structure of Islamic mysticism and cognitive science is the basis of human-centered architecture. Clifford Geertz's Theory of Interpretation and The Fuzhou Bowie's Religious Anthropology as well as Max Lusher's Psychology of colors have been identified as theoretical framework.

\section{Shadow and Light of Creation in Architecture:}

It is written in mysticism that God created the world in darkness and then blown it out of its light. (Zamr, 29) the essence of being has considered black and dark, and sometimes it refers to absolute absenteeism, since no one has anything to do with it, so it has been said the unseen. Because of its inextricable visibility, it looks like the night, because it can not be detected anything at night and the same, there is no understanding of the nature of the phenomenon in existence. (Shaygan, 2003: 253). But the creation from which the unseen begins is called light.

It brings some kind of light and darkness together. Ayn al-Kudash Hamedani in the first chapter of his letters says: "The first thing that God created was the light of Muhammad and the light of Satan" and in Zoroastrianism this darkness is interpreted as Ahura Mazda and Ahriman. Architecture is also defined the light and the shadow. Because the space makes light in shadows, then darkness comes to light, and the light brings darkness to the full and empty universe. Absolute darkness and absolute light, with the shadows of the desert, make meaning to the human objectivity. Because this shadow and brightness complement each other. The Fein Kashan bath and the Qazvin bazaar, which illuminate from the ceiling and valves, are examples of this shadow and are bright (Siroos, 2015: 51). They also depict depth and dimension; the light is the symbol of divine wisdom and becomes the element of all goodness. Because moving from dark to light was the main goal. (Jahanbakhsh, 2015: 40) Mahmoudi also believes that light in the dark carry's messages and references to humans. The light is in fact a guideline in the spaces and paths of input and output at night, and what defines these messages is the light of color that is scattered throughout the environment. (Mahmoudi, 2015, 20)

The interpretation of color and light in the universe stages: According to the mystics, the degrees of the universe have special color and light due to its capacity and transparency, and light is donated to the effects of absolute existence, and the creatures, in proportion to the light of God, enjoy the light and the existence, and the material beings have the weaker and darker light than the creatures of the universe. Therefore, light is introduced as the epitome of existence in architecture. (Madadpour, 1995, 271), and these stages include:

1) The universe of reason, 2) The universe of the soul, 3) The world of the soul, 4) The universe of example, 5) The universe of nature, 6) The universe of matter, 7) The universe of the object. These seven universes, according to their closeness \&dimension, receive a special color from the source of light, which is God, which each of them has the special meaning in architecture, which is used by a well-known architect to express the universe of its own color. And now we will describe each of these worlds with their special light.

The wisdom of the universe: it is white because of this unity, and in the opinion of the painters, whenever a combination color with its complement is added, white light will come. Of course, white light is produced when each color has a 50\% share and is evenly blended together, and all light sources are not capable of producing a completely white light. In fact, very few light sources create white light. (Seyyed Sadr, 2007: 127) So a white is in the light of the presence of all the colors, the white color for the Greek Parthenon means "virginity", and in the frame of Athena 
(Athene) is the main color that most western brides wear in the white color (Mahmoudi and Shakiba Manesh, 2011: 3). Because white dresses make happiness, the Prophet (pbuh) also said "there is no color in your clothes better than white. Use such a dress, and shave your dead with a white cloak". (Stable, 2012: 12)

Hindus wear white dresses in the mourning ceremony, which is the sign of the deceased'sescort to the heaven and perfection. In the Buddhist religion, the white color is a sign of self-control and salvation, and in Christianity it is a symbol of the spirit of purity and virginity. So that the wisdom of the wisdom is referred to white because it is an indication of the lack of distinction and transcendental perfection and simplicity, and the divine presence in Islamic architecture represents as uniform and unobtrusive mosques, the same simplicity is a reminder of the absolute richness. (Nasr, 1991: 68)

The Spirit of the universe: The color of the universe of the soul is yellow because it is in the midst of the universe of reason and the universe of the soul, that is, between the universe of meaning and the universe of the matter. In China, yellow is the blazing color of the Emperor. The Chinese consider the Emperor as the Son of God, and believe that no one other than him has the right to wear yellow dress. Yellow in the ancient Chinese culture was a symbol of supreme wisdom (Johann Etienne, 2012: 11) Hindu brides wear antique yellow dresses in India for six days before the wedding, to bring evil spirits away. At the marriage ceremony, the bride and the priest who draws the marriage wear both yellow dresses. The yellow and golden colors are holy colors as the hallmark of the baptismal ritual. (Mahmudi and Shakibamanesh, 2011: 20)

In the architecture and mysticism, the mystic, aims to leave the body and to reach unity through the mystical path and this is shown in the gilding of the domes. Because gold is the highest element that represents the emancipation of man from the soul and becoming a perfect human being. The mirror and the Mogharnas of holy places are used to escape from the thick wall of mud and body. You see in that environment only light and white. We must also be free from the body.

The world of the soul: The color of the universe is green. In architecture, this color is represented in the form of a circle. This form, which is characterized by balance, coordination and support, is shaped as rounded and without sharp edge, and reflects all the characteristics of the green color. The circle is a symbol of security, freedom and non-imposition on others, no matter which direction it is heading to, because it does not undergo any change and will remain constant. (Mahmudi and Shakibamanesh, 2011: 14) The green color comes from the combination of green and blue. The dominant colors in Iran's paintings and architecture are green and blue, with colors like red and yellow, earthy and azure, bright, colorful colors that show softness and delicacy, the beauty of the other world. (Pakbaz, 2001: 68)

Example universe: The color of this universe is dark green. Because the example world is closer to the material world than the soul, so green color becomes darker. Because whatever these realms are going up, they are brighter, and the lower, they become darker. Because the universe has the form and the size of the example, it is related to the material world, so it gets darker.

The universe of nature: The color of the universe is red. In the Chinese religions, the red color is considered a symbol of life. For this reason, the girl who is going to marry wears red dress, and in the old days they painted the walls of Beijing with a red color to symbolize the ghosts (Mahmoudi and Shakiba Manesh, 2011, 4)

The material universe: the color of the universe is gray.

The universe of the body: The color of the universe is black. The black was the symbol of death. In the book Psychology of Colors, Max Luscher wrote: "The black color represents the absolute boundary. A woman wearing a black hijab creates a perfect boundary between her own and strangers. " (Reza'i, 2017: 14)

\section{LIGHT APPLICATION IN ARCHITECTURE}

According to these seven worlds and their color variations in Islamic mysticism, the color and light in the architecture also find their own meaning, and the colored glasses and valves used in the roofs and walls of the mosques represents those realms in order to goes the viewer from the material world to the world of meaning. Old architects designed the space content by emitting light and guiding it from the opening on the ceiling, and by placing colored glass on the path of light propagation, they incited various colorful designs in space. One of the masterpieces of Iranian architecture is the combination of light with the architecture of the dome of the mosque Sheikh Lotfollah and the well - known figure as Tavos Noor. The architects created an empty pillar of light in the focal axis of the space, between the roof of the roof and the floor figure of a column, that became visible through the presence of man to remind of unity and spirituality, and to create a sense of sanctity and respect (Eslami, 2015: 62). The light used in the Ali Qapu Mansion is a shamrock and the shadows and lights play a kind of spatial confidentiality. (Mahmudi, 2015: 98). Therefore, in the architecture of light, it is considered as the manifestation of the existence, and the mirror and the use of mosaics with golden and turquoise colors are an expression of the effect of light. And the stone and brick of mosques emit light mysteriously, and they differ in other stones such as ruby diamonds with other stones (Burkhart, 1997: 57). 
The combination of light and color in human behavior In Ala al-Dawlah Semnani 's Nooriya treatise, the color has interlaced with light. In a beautiful, elegant illustration, he finds a beginner's seeker sitting in a quiet place where light and color are intertwined, he sees the brightness, which has been strengthened due to the "rosary" and opens a circular in front of the seeker. From this circle, seven colors go upward, like a spring of water. These seven colors are the same seven colors that you should see in the climbing arc in the seven delicate things, and with the help of each one's light, you will break many veils. The intersection of color and light in the mystical thought of Alaa al-Dawlah Semnani is associated with a kind of mystical physiology. However, it compares seven internal human ventures with the seven inner meanings of the Holy Qur'an, and for each of these inner aspects of man, he puts in a special color and light:

1. Physical body: It starts with a delicate frame and does not form, it comes from the world of life, and it calls the "Adam of Your Existence", which is related to Adam, who originates from the world of the existence. And has a cool and dark color. Because the seven steps are far from the delicate of truth, and whatever is closer to the material world, it will be darker. Ala al-Dawlah Semnani sees this color as the shroud of the devil, when the seeker faces it in the first step.

2. Ego Body: This body is the seat of the soul, and it is for the presence of filthy pleasures and desires, and because it is not too far from the body, it is called the face world. And when it encounters less than itself, it finds the position of Noah, who faces the enemies with blue eyes. Because the soul overcame the material's turbidity and is based on the universe (Semnani, 1371, 3). So, the ancient Egyptians used a blue combination as a symbol of divinity, truth, and perfection, and later appeared in the image of Mary the Exhalation. And used to cover the altars and tables of preaching in Greece, and it is shown in a circle because it gives the person a sense of tranquility when he/she sees the circle. And the circle is a symbol of the soul and the blue color creates depth and spiritual space, and the Chinese form the rectangles in front of the circle, the palaces of the world and mortals of the Sultans.

3. Cardiac body: This organ is a place for a spiritual being in the heart of man. This is the image of "Abraham of your existence", which is another image of the universe.

4. The Secret body: A secret delicate body that in the imagination of the universe is the secret conversation with the Lord. "The Mystery of Your Existence" is a white color that has green beams in its text and occurs in this discovery.

5. Moral Body: This delicate is the image of the universe and beyond the face, and "Davood of your existence " and is yellow in color same as the words of the Holy Qur'an (Surah Baqara, verse 69)

6. Hidden body: which represents the divine nature in the above universe. It is called "Jesus of your existence." The inspirations of the soul are received by this body and is bright in color, because it is the secret of hidden secrets.

7. True Body: This delicate is known as the state of truth or the essence of nature and is called "Muhammad is your existence ". This body is the image of the true human being, which is the lighted man who traveled through seven ventricles and communicated with it seven colors (Semnani, 1990, 307)

Each of the stages are called under the name of the prophets due to this fact that each prophet was the manifestation of that stage, and more distinct from other stages. That is why Mohiuddin Ibn Arabi was also in The book of Fusus al-Hakam called the name of each prophet with his particular wisdom and has named that episode in the name of that prophet. This mystical insight based on color and light on art also had a profound effect and displayed more in painting and architecture and became an external mirror for this spiritual journey.

For this reason, Henry Carbon considers the Iranian painting philosophy to lead an insight beyond the sensory world that inspires the adulation and praises of the "boys of light" and the fear of "dark boys", which represents the righteous and subtle body of the luminous human to the escape of the darkness (Carbon, 2000). This is what Louis Massignon calls the Iranian artist's alchemy- like work to release the pieces of light from the prison of matter, and see it as an attempt to embody the paradise and natural nature, an early example of the current example in the universe. (Nasr, 1996: 175)

\section{CONCLUSION.}

The universe is created from the divine luminous principle and moves down to the material world and traverses' different realms, and in every universe, it takes its light and light universe, gradually that light becomes darker and darker, finally it becomes black and silent when it reaches the universe of matter. Again, through the guidance of the prophets and the revelations of the mystics, the human begins move from this material world to the exalted world, and sees the light within them. The hard work of the architect is to show these realms and their special 
light in the material world through artificial light, glass and valves, and it makes us come to a conclusion.

1. The same concern that exists in Islamic mysticism to express how the universe is created by God. There is also a concern in architecture. And the work of the architect who wants to make theoretical debates with stone and clay, is more difficult.

2. That essence stance is considered as the Absolute Unseen and have considered it black because it is in the universe of all the names and attributes of the attributes of nature, and that the black light is also due to the lack of color and this fact that the material universe is also black. This blackness in matter is due to the combination of color variants. When God comes down from the Almighty once, it manifests itself in the universe. The light appears and its color is white because the light of lights has all the light. White color of light also contains all the colors. The closer to the material world, the darker in its dark world. This theme is well illustrated in the architecture of shadows and lights and the manifestation of light from the ceiling of mosques and markets.

3. Creation and the return of man and universe to God in the mysticism are shown as the arch of ascension and descend. It is shown in circular architecture of domes and colors of gold, purple, blue used in gilding, painting, tiling and mirroring of domes.

\section{BIBLIOGRAPHIC REFERENCES}

Ardalan, Nader \& Bakhtiar, Laleh. (2001). The advantage of Unity, the mystical tradition of Iranian architecture, translated by Hamid Shahrokh. Khak Publishing House.

Burkhart, Titus. (1991). Immortality and Art. Translated by Seyed Mohammad Avini, Tehran, Barg Publishing.

Burkhart, Titus. (1997). The Basics of Spiritual Art. Tehran, Soreh Publications.

Carbon, Henry. (2000). Illuminated Man in Iranian Sufism. Translated by Faramarz Joohrania. Tehran, Golban Publishers.

Cardinell, Helen. (2015). Art in Time, Translator, Mohammad Taghi Faramarzi, Tehran. Aja Bahar Publication, Sixth Edition.

Fakouhi, Nasser. (2007). History of the Ideas and Theories of Anthropology. Sixth Printing, Tehran: Ney Publishing.

Golabchi, Mahmoud. (2014). Technological architecture of Iran. Tehran University Press, Tehran University Press.

Johannes, Etten. (2012). Painting Art, Translated by Arabali Sherveh. Pawli Publishing.

Madadpour, Mohammad. (1995). Manifestations of Spiritual Wisdom in Islamic Art. Tehran, Amir Kabir

Mahmoudi, Cyrus \& Shakibamanesh, Amir. (2011). Principles and Principles of Colorology in Architecture and Urban Planning, Tahan Publications / Hell.

Mahmoudi, Mohammad Mehdi (2015). Light, Color and Sound in Art, Architecture and Urbanism, The article "Light of Transition between Humans" by Reza Mansouri, Azarakhsh Publications.

Mahmoudi, Mohammad Mehdi. (2015). "Environmental Management of Urban Lighting" by Reza Mansouri, Azarakhsh Publications.

Mahmoudi, Mohammad Mehdi (2015). "The Effect of Using Light in Urban Buildings," by Haydar Jahan Sattar, Azarakhsh Publications.

Najiboglu, Golrou. (2000), Geometry and Decoration in Islamic Architecture, translated by Mehrdad Ghiyomi Bidhendi, Tehran, Rozaneh Publishing.

Nasr, Seyed Hossein. (1991) Immortality and Art, translated by Seyyed Mohammad Avini, Tehran, Barg Publishing.

Nasr, Seyyed Hossein. (1982). Three Muslim Wise Persons, Translation by Ahmad Aram, Tehran, Pocket Books Publishing.

Nasr, Seyyed Hossein. (1996). Islamic Art and Spirituality, translation by Rahim Ghasemian, Tehran, Department of Religious Studies.

Ostovar, Mosayyeb. (2012). Color, Tehran, Raznameh Publishing

Pakbaz, Rouen. (2001). Iranian Painting from Yesterday to Today, Zarrin and Simin Printing.

Rezaei, Ismail. (2017). Review of the Effect of Kashm Chilipa Desert with Abcoeological Approach, Tehran, Fardabeh.

Semnani, Alaa al-Dawlah. (1990). Farsi Mentals, by Najib Melli Heravi, Tehran: Scientific and Cultural Publishing.

Shayegan, Dariush. (2003). Hinduism and Islamic mysticism, translation by Jamshid Arjomand, Farzan Rooz Publication.

How to cite this article: Mazaheri, S., \& Mazaheri, A. (2020). Light and color in Islamic mysticism and architecture. Religación. Revista De Ciencias Sociales Y Humanidades, 5(23), 177-181. Retrieved from http://revista.religacion.com/index.php/ religacion/article/view/613

Submitted: 28 November 2020 Accepted: 09 March 2020 Published: 31 March 2020

Religación. Revista de Ciencias Sociales y Humanidades is a peer-reviewed open access journal published by CICSH-AL Centro de Investigaciones en Ciencias Sociales y Humanidades desde América Latina |Religación| 